\title{
SPATIAL FACTORS OF ASSESSMENT OF COMFORT OF THE URBAN ENVIRONMENT OF A LARGE CITY
}

DOI: $10.32620 /$ cher.2021.2.09

Formulation of the problem. The conditions and spatial factors for the implementation of national projects are considered. On the example of a large city, the factors of the comfort of the urban environment of a large city are assessed. Variants of effective combination of spatial urban complexes are identified. The purpose of the article is to analyze the spatial factors of assessing the comfort of the urban environment in a large city. The subject of the research is the process of assessing the comfort of the urban environment in a large city. Analytical, historical, statistical, logical, comparative methods were used as research methods. Research hypothesis. By the comfort of the urban space, the authors understand not only the level of the amenities of the adjoining territories, which the developers create at a high aesthetic and practical level. This refers to the convenience of receiving social services and their transport accessibility. Therefore, having successfully sold apartments of the first stage, the developer may and is faced with the problem of selling apartments of the second and subsequent stages of construction. Presentation of the main material. The authors of the article propose to use the original aggregate indicator for the purposes of assessing the comfort of the city - the index of the comfort of the urban environment, with a form already successfully tested in other studies, consisting of 35 private indicators combined into 7 sections: geographical location, level of development of public transport, state of the environment. environment, the level of development of social infrastructure (combined in 3 sections), the arrangement of the adjoining space. Originality and practical value. The problem of the housing stock deficit is gradually weakening and replaced by the problem of the excess of the supply of housing over the demand for it. In the new conditions, a potential buyer of an apartment is interested not only and not so much in its size and price, but also in the environment surrounding the chosen house. On the other hand, the commercial interest of the developer was traditionally manifested in the desire to sell the apartment soon. Research conclusions and prospects for further research. The comfort of the urban environment is becoming an increasingly monetized element of the total cost of purchased housing. Competent use of information about it makes it easier for the developer to offer and sell a particular apartment. In addition, the indicator of the comfort of the urban environment can be actively used in applied studies, for example, in geomarketing research.

\section{Key words:}

national projects, spatial factors, large city, comfort of the urban environment.

\section{ПРОСТОРОВІ ФАКТОРИ ОЦІНЮВАННЯ КОМФОРТНОСТІ МІСЬКОГО СЕРЕДОВИЩА ВЕЛИКОЇ МІСТА}

Постановка проблеми. Розглядаються умови і просторові чинники реалізації національних проектів. На прикладі великого міста оцінюються чинники комфортності міського середовища великого міста. Виявляються варіанти ефективного поєднання просторових міських комплексів. Мета статті - проаналізувати просторові чинники оцінки комфортності міського середовища великому місті. Предмет дослідження - процес оценірованія комфортності міського середовища у великому місті. В якості методів дослідження застосовувалися аналітичний, історичний, стати-стіческій, логічний, порівняльний. Гіпотеза дослідження. Під комфортністю міського простору автори розуміють не тільки рівень впорядкованості прибудинкових територій, які забудовники створюють на високому естетичному і практичному рівнях. Мається на увазі комфортність отри-

${ }^{1}$ Сидоров Валерій Петрович, канд. геогр. наук, доцент, завідувач кафедри географії, картографії та геоінформатики, завідувач лабораторії просторових досліджень «UrbanGEOlab», Удмуртський державний університет, м. Іжевськ, Росія.

Sidorov Valery, Ph.D. Geography, Associate Professor, Head of Geography, Cartography and Geoinformatics Department, Head of the Spatial Research "UrbanGEOlab" Laboratory, Udmurt State University, Izhevsk, Russia.

ORCID ID: 0000-0002-1434-5372

e-mail: sidorov@udm.ru

${ }^{2}$ Ситніков Павло Юрійович, асистент кафедри географії, картографії та геоінформатики, старший науковий співробітник лабораторії просторових досліджень «UrbanGEOlab», Удмуртський державний університет, м. Іжевськ, Росія.

Sitnikov Pavel, Assistant of Geography, Cartography and Geoinformatics Department, senior researcher of of the Spatial Research "UrbanGEOlab" Laboratory, Udmurt State University, Izhevsk, Russia.

ORCID ID: 0000-0001-1344-3574

e-mail: sitnikov-geo@yandex.ru 
мання соціальних послуг та їх транспортна доступність. Тому, успішно продавши квартири першої черги, забудовник може зіткнутися і стикається з проблемою реалізації квартир другої і наступних черг будівництва. Виклад основного матеріалу. Автори статті пропонують використовувати для цілей оцінки комфортності міста оригінальний агрегований показник - індекс комфортності міського середовища, 3 уже успішно апробованої в інших дослідженнях формою, що складається з 35 приватних показників, об'єднаних у 7 розділів: географічне положення, рівень розвитку громадського транспорту, відбутися у-яние навколишнього середовища, рівень розвитку соціальної інфраструктури (об'єднаних в 3 розділу), облаштованість прибудинкової простору. Оригінальність і практичне значення. Проблема дефіциту житлового фонду поступово послаблюється і замінюється проблемою перевищення пропозиції житла над попитом на нього. У нових умовах потенційного покупця квартири цікавить вже не тільки і не стільки ії заходів і ціна, а й середовище, що оточує обраний будинок. 3 іншого боку комерційний інтерес забудовника традиційно проявлявся в бажанні швидкого продажу квартири. Висновки дослідження і перспективи подальших досліджень. Комфортність міського середовища стає все більш монетизованим елементом загальної вартості житла, що купується. Грамотне використання інформації про нього полегшує забудовнику процедуру пропозиції і продажу конкретної квартири. Крім того, показник комфортності міського середовища можна активно використовувати і в прикладних, наприклад, в геомаркетингових дослідженнях.

Ключові слова:

національні проекти, просторові чинники, велике місто, комфортність міського середовища.

\section{ПРОСТРАНСТВЕННЫЕ ФАКТОРЫ ОЦЕНКИ КОМФОРТНОСТИ ГОРОДСКОЙ СРЕДЫ БОЛЬШОМ ГОРОДЕ}

Постановка проблемы. Рассматриваются условия и пространственные факторы реализации национальных проектов. На примере крупного города оцениваются факторы комфортности городской среды крупного города. Выявляются варианты эффективного сочетания пространственных городских комплексов. Цель ста$m b u$ - проанализировать пространственные факторы оценки комфортности городской среды большом городе. Предмет исследования - процесс оценирования комфортности городской среды в крупном городе. В качестве методов исследования применялись аналитический, исторический, статистический, логический, сравнительный. Гипотеза исследования. Под комфортностью городского пространства авторы понимают не только уровень благоустроенности придомовых территорий, которые застройщики создают на высоком эстетическом и практическом уровнях. Имеется в виду комфортность получения социальных услуг и их транспортная доступность. Поэтому, успешно продав квартиры первой очереди, застройщик может столкнуться и сталкивается с проблемой реализации квартир второй и последующих очередей строительства. Изложение основного материала. Авторы статьи предлагают использовать для целей оценки комфортности города оригинальный агрегированный показатель - индекс комфортности городской среды, с уже успешно апробированной в других исследованиях формой, складывающийся из 35 частных показателей, объединенных в 7 разделов: географическое положение, уровень развития общественного транспорта, состояние окружающей среды, уровень развития социальной инфраструктуры (объединенных в 3 раздела), обустроенность придомового пространства. Оригинальность и практическое значение. Проблема дефицита жилого фонда постепенно ослабляется и заменяется проблемой превышения предложения жилья над спросом на него. В новых условиях потенциального покупателя квартиры интересует уже не только и не столько ее размеры и цена, но и среда, окружающая выбранный дом. С другой стороны, коммерческий интерес застройщика традиционно проявлялся в желании скорой продажи квартиры. Выводы исследования и перспективы дальнейших исследований. Комфортность городской среды становится все более монетизированным элементом общей стоимости приобретаемого жилья. Грамотное использование информации о нем облегчает застройщику процедуру предложения и продажи конкретной квартиры. Кроме того, показатель комфортности городской среды можно активно использовать и в прикладных, например, в геомаркетинговых исследованиях.

\section{Ключевые слова:}

национальные проекты, пространственные факторы, крупный город, комфортность городской среды.

Formulation of the problem. Housing, the availability of personal living space is one of the most important basic human needs. For the entire Soviet and early post-Soviet periods of Russian history, the average man in the street was quite satisfied with the very fact of receiving or acquiring an apartment. Its quality in the list of priorities was in second place, and the quality of the space surrounding the house was in third. Nowadays, the development of construction technologies, the emergence of more advanced structural materials and construction mechanisms have significantly accelerated the very process of building buildings. The developed system of mortgage lending stimulates the growth of the purchasing power of the population. As a result, in almost all large Russian cities, a process of mass housing construction unfolded, which is rapidly changing the geography of population settlement in large cities. The problem of the housing stock deficit is gradually weakening and replaced by the problem of the excess of the supply of housing over the demand for it. In the new conditions, 
the potential buyer of an apartment is interested not only and not so much in its size and price, but also in the environment surrounding the chosen house. On the other hand, the commercial interest of the developer was traditionally manifested in the desire to sell the apartment soon. The problem of the comfort of the urban environment was relegated to the background. In this case, the authors understand the comfort of the urban space not only as the level of the amenities of the adjoining territories, which the developers create at a high aesthetic and practical level. This refers to the convenience of receiving social services and their transport accessibility. Therefore, having successfully sold apartments of the first stage, the developer may and is faced with the problem of selling apartments of the second and subsequent stages of construction [2].

\section{Analysis of recent research and publica-}

tions. Having successfully sold apartments of the first stage, the developer may and is faced with the problem of selling apartments of the second and subsequent stages of construction [2]. If the quality of the offered apartments is equal, the developer who offers a comfortable environment around the house in the same package with the apartment will win. The need to assess the comfort of the urban environment in Russia has been talked about in the last 5-6 years.

However, the reaction speed of the relevant authorities was significantly reduced by the weak methodological support at the initial stage of both the above project and the municipal program, which determined the choice of the topic of the proposed research.

Initially, documents $[5,6]$ provided for the use of 4 indicators (indicators) to assess the comfort / quality of the urban environment: the number and area of landscaped courtyards; the share of landscaped courtyard areas of apartment buildings from the total number of courtyard areas; the number of landscaped public areas within the framework of the priority project; the area of landscaped public areas within the framework of the priority project within the framework of the priority project. But the above indicators allow us to assess only the well-being of city courtyards. But not the comfort of the urban environment. And even then it is very conditional, since the content of the concept of "livability" is not concretized.
The purpose of the article is to analyze the spatial factors of assessing the comfort of the urban environment in a large city.

Presentation of the main material. The use of the above indicators of comfort, originally proposed by the Ministry of Construction, was doomed to failure in advance due to the large capacity of the very concept of "comfort of the urban environment". Comfort is the optimal state of the surrounding social, economic, natural, infrastructural environment for a person, which ensures the health and performance of individuals or their communities [7]. Its level is assessed by a whole group of different-sized, multidirectional indicators, some of which have no quantitative form. For their successful joint use, it is necessary to use an aggregated, integral, that is, a composite indicator.

One of the first to use integral indicators for assessing the quality of the urban environment was the Institute of Spatial Planning "Urbanika" from St. Petersburg [8], which proposed the "Rating of the quality of the living environment" of residential complexes, based on mathematical and visual analysis of 30 criteria, combined into 6 groups. Namely: the distance from the object to the border of the center of St. Petersburg, to the nearest urban subcenter, the presence of cultural, historical and recreational attractors, environmental tension, sociotype of the area, building density, quality of the environment, pedestrian accessibility of public transport stops, educational and healthcare institutions, commercial services, the layout of the quarter, the availability of parking, the organization of road and pedestrian traffic, the improvement of the quarter, the articulation of the first floors, the quality and style of the facade, the quality and variety of commercial and social functions within the first floors, the quality, landscaping and accessibility of the courtyard area, safety and organization open areas, typology of residential buildings, the level of self-organization of residents, isolation of households [8]. With its obvious advantages, the technique has such significant disadvantages as:

- the use of the scoring method, which does not allow to fully take into account the differences in the absolute values of indicators, thus "coarsening" the final result;

- controversial distribution of weights by groups of indicators;

- the dominance of indicators of the architectural and planning component - to the 
detriment of indicators of the provision of social infrastructure facilities.

At present, the Moscow-based company KB Strelka has been chosen by the Russian Ministry of Construction as the monopoly supplier of the methodology for such assessments.

At the end of 2019, the Ministry of Construction of Russia published the first (according to officials of the Ministry) urban environment quality index for more than 1,110 settlements in Russia [9]. The calculations were based on the method proposed by the Strelka Design Bureau (Moscow) [10]. The urban environment quality index is an aggregate indicator that includes 36 indicators, rated on a ten-point scale. The sum of the indicator values shows the quality level of the urban environment (maximum 360 points). The indicator is approved at the federal ministerial level and is recommended for use and is already in use.

According to the authors of the article, the above index is far from perfect. If there are no serious complaints about the list of indicators. But the point (from 0 to 10) methodology for assessing each indicator looks too simple. Indicators are not standardized, not weighed, which is unacceptable. And the final division of settlements into only two groups: with a favorable urban environment and an unfavorable one does not at all stand up to criticism. That is, a locality that scored more than 180 points has a favorable urban environment, while one that scored 179 points is already unfavorable for living. In addition, the technique is suitable only for point objects, but not for areal ones.

The authors of the article propose to use an original aggregate indicator for such purposes - the urban environment comfort index (ICUE) (with the form already successfully tested in other studies [10]), which consists of 35 private indicators combined into 7 sections: geographical location, level of public transport development, the state of the environment, the level of development of social infrastructure (combined into 3 sections), the arrangement of the adjoining space.

As a methodological result of the study, we can consider the proven possibility of using integral aggregated indicators (the same index of comfort of the urban environment - ICUE) to assess complex multicomponent phenomena. The formula for calculating the ICUE has the following form (1):

$$
\operatorname{ICUE}_{i}=\sum_{i=1}^{m} k_{j} b_{i j}^{n}
$$

where: $I C U E_{i}$ is the index of the comfort of the urban environment of the $\mathrm{i}$-th microdistrict, residential complex or house;

$b_{i j}^{n}$ is the normalized value of the $j$-th indicator of the quality of the urban environment of the i-th microdistrict, residential complex or house;

$\mathrm{k}_{\mathrm{j}}$ is the weight coefficient of the $\mathrm{j}$-th indicator of the comfort of the urban environment;

$\mathrm{k}_{\mathrm{j}}=\frac{\mathrm{I}_{\mathrm{j}}}{\mathrm{I}_{\max }}$, where $\mathrm{I}_{\mathrm{j}}$ is the informativeness of the $\mathrm{j}$-th indicator, determined by summing all the correlation coefficients of the $\mathrm{j}$-th indicator with other indicators;

$I_{\max }$ is the maximum value of information content among all used indicators.

The greater the absolute value of ICUE, than in more comfortable conditions the microdistrict, residential complex or house is located.

The developed indicator was used to assess the comfort of the urban environment in the new buildings of Izhevsk. The work was carried out in the second half of 2019. Comfort was measured in 247 residential buildings and residential complexes built from 2015 to 2019 , as well as those under construction with a deadline for commissioning in 2020-2021. The results were compiled into large graphical forms in Microsoft Excel (Table 1).

Table 1: Rating of developers in the city of Izhevsk by ICUE (arithmetic mean)

\begin{tabular}{|c|l|c|c|}
\hline Location & \multicolumn{1}{|c|}{ Developer } & $\begin{array}{c}\text { Number of } \\
\text { objects }\end{array}$ & Arithmetic mean \\
\hline 1 & Region-Invest & 8 & 12,656 \\
\hline 2 & GK Atlant (April) & 2 & 11,767 \\
\hline 3 & UralDomStroy & 23 & 11,390 \\
\hline 4 & ACCO-Cтрой & 8 & 10,848 \\
\hline 5 & ITS City & 3 & 10,680 \\
\hline$\ldots$ & \multicolumn{1}{|c}{$\ldots$} & $\ldots$ & $\ldots$ \\
\hline$\ldots$ & StroyGroup & $\ldots$ & $\ldots$ \\
\hline 28 & Roman square & 1 & 8,797 \\
\hline 29 & LLC "Key" & 1 & 8,562 \\
\hline 30 & Izh-Grad & 1 & 8,514 \\
\hline 31 & LLC "Hills 2" ("Zardon") & 1 & 7,791 \\
\hline 32 & &
\end{tabular}

Source: calculated by the authors 
Based on the results of the study, the rating of the developers of the city of Izhevsk was determined by the value of ICUE, the objects they have built or are under construction: both by the arithmetic mean value and by the median.

Conclusions and prospects for further research. The comfort of the urban environment is becoming an increasingly monetized element of the total cost of purchased housing. Competent use of information about it makes it easier for the developer to offer and sell a particular apartment. In addition, the indicator of the comfort of the urban environment can be actively used in applied studies, for example, in geomarketing research.

The comfort of the urban environment is a multicomponent phenomenon in its composition and should be measured using integral indicators

The calculations carried out by the authors proved the methodological efficiency of the proposed index of the comfort of the urban environment, showed the possibility of using the index of comfort in relation not only to urban conditions, but also to rural areas.

Cartographic images constructed on the basis of calculations allow you to visually show the territories of Izhevsk, which can be considered more prestigious or not.

\section{References}

1. National project "Formation of a comfortable urban environment". Retrieved from: // https: //nationalprojects.rf/projects/zhile-igorodskaya-sreda/blagoustroystvo.

2. Sidorov, V. P. (2019). Comfort and contrast of transboundary urbanized spaces. Actual problems of earth sciences: studies of transboundary regions: collection of articles. materials IV Int. scientific-practical conf., timed. to the 100th anniversary of the city of Brest, 12-14 Sept. 2019 Brest: BrSU, 1, 283-286.

3. Sidorov, V. P. (2018). State regulation of the urban environment. Regional Development: Problems and Prospects: Materials of the VII All-Russian Scientific and Practical Correspondence Conference with International Participation. Neftekamsk: NF BashGU, 22-26.

4. Methodological recommendations for the preparation of state programs of the constituent entities of the Russian Federation and municipal programs for the formation of a modern urban environment as part of the implementation of the priority project "Formation of a comforta- ble urban environment" for 2018-2022, approved by order of the Ministry of Construction, Housing and Utilities of April 6, 2017 № 691/pr.

5. The municipal program "Formation of a modern urban environment on the territory of the municipal formation" City of Izhevsk "for 2018-2022", approved by the resolution of the Administration of the city of Izhevsk dated 09.29.2017 № 428.

6. Sidorov, V. P. (2018). The problem of assessing the comfort of urban space. Siberian city in the focus of humanitarian research: to the 400th anniversary. Collection of articles of the All-Russian scientific-practical conference with international participation, Novokuznetsk, October 25-26. Novokuznetsk: NFI KemSU; "Art Express", 339-342.

7. Rating of the quality of the living environment: a detailed description of the methodology. // Urbanica. Retrieved from: http://urbanica.spb.ru/research/ratings/rejtingkachestva-zhiloj-sredy-podrobnoe-opisaniemetodologii/.

8. Ministry of Construction and Housing and Communal Services of the Russian Federation. Urban environment quality index. Retrieved from: https: //index-gorodov.rf/\#/.

9. Strelka, K. (2020). Urban Environment Quality Index project. Retrieved from: https://strelka-kb.com/.

10. Sidorov, V. P., Sitnikov, P. Yu. and Rubtsov, V. A. (2020). Evaluation of the comfort of the urban environment (for example, the city of Izhevsk). Bulletin of the Udmurt University. Series: "Biology. Earth Sciences ", 30, 2, 244-254.

11. Sitnikov, P. Yu. (2020). Comfort of the urban environment of new housing construction objects on the territory of Izhevsk. Digital geography: materials of Vseros. scientific-practical conf. with int. participation, 16-18 Sep., Perm: PSNIU Publishing House, 95-98.

12. Sitnikov, P. Yu. (2019). Application of GIS in geomarketing research. Problems of regional ecology and geography: materials of the international. scientific-practical conf., October 7-10. Izhevsk: Udmurt University, 264-267.

\section{Література}

1. Національний проект «Формування комфортного міського середовища». [Електронний ресурс]. URL: https: //національниепроекти.pф/projects/zhile-igorodskaya-sreda/blagoustroystvo. 
2. Сидоров В. П. Комфортність і контрастність транскордонних урбанізованих просторів. Актуальні проблеми наук про Землю: дослідження транскордонних регіонів: зб. матеріалів IV Міжнар. наук.-практ. конф., приурочені. до 1000-річчя м Бреста, 12-14 сент. 2019 р Брест: БрДУ, 2019. Ч. 1. С. 283286.

3. Сидоров В. П. Державне регулювання міського середовища. Регіональний розвиток: проблеми і перспективи: матеріали VII Всеукраїнській науково-практичній заочна конференція 3 міжнародною участю. Нефтекамськ: НФ БашГУ, 2018. С.22-26.

4. Методичні рекомендації з підготовки державних програм суб'єктів Російської Федерації і муніципальних програм формування сучасної міського середовища в рамках реалізації пріоритетного проекту «Формування комфортного міського середовища» на 20182022 роки, затверджених наказом Міністерства будівництва і житлово-комунального господарства від 6 квітня 2017 року № 691.

5. Муніципальна програма «Формування сучасної міського середовища на території муніципального освіти «Місто Іжевськ» на 2018-2022 рр.», Затверджена постановою Адміністрації м. Іжевська від 29.09.2017 р № 428.

7. Сидоров В. П. Проблема оцінки комфортності міського простору. Сибірський місто в фокусі гуманітарних досліджень: до 400-річчя. Збірник статей Всеросійської науково-практичної конференції 3 міжнародною участю, м Новокузнецьк, 25-26 жовтня 2018

\footnotetext{
Стаття надійшла

до редакції : 25.03.2021 p.
}

p. Новокузнецк: НФІ КемГУ; «Арт-експрес», 2018. С. 339-342.

8. Рейтинг якості житлового середовища: докладний опис методології. Урбанік. [Електронний pecypc]. URL: http://urbanica.spb.ru/research/ratings/rejtingkachestva-zhiloj-sredy-podrobnoe-opisaniemetodologii.

9. Міністерство будівництва та житлово-комунального господарства РФ. Індекс якості міського середовища. [Електронний pecypc]. URL: https: //індекс-городов.pф/\#/. Дата звернення: 20.01.2020.

10. Стрілка К.Б. Проект «Індекс якості міського середовища». [Електронний ресурс]. URL: https://strelka-kb.com/.

11. Сидоров В. П., Ситніков П. Ю., Рубцов В. А. Оцінка комфортності міського середовища (на прикладі міста Іжевськ). Вісник Удмуртського університету. Серія: «Біологія. Науки про Землю», 2020 р Т.30, Вип. 2. Іжевськ: УДГУ, 2019. С. 244-254.

12. Ситников П. Ю. Комфортність міського середовища об'єктів нового житлового будівництва на території Іжевська. Цифрова географія: матеріали Всерос. наук.-практ. конф. 3 міжнар. участю, 16-18 сент. 2020 р. Пермь: Вид-во ПГНІУ, 2020. С. 95-98.

13. Ситников П. Ю. Застосування ГІС в геомаркетингових дослідженнях. Проблеми регіональної екології та географії: матеріали міжнар. наук.-практ. конф., посвящ. 100-річчя конструктора М.Т. Калашникова і 100-річчю професора С.I. Широбокова, 7-10 жовтня 2019 p. Іжевськ: Удмуртська університет, 2019. C. 264-267.

\section{Стаття прийнята \\ до друку: 30.06 .2021 p.}

Бібліографічний опис для цитування :

Sidorov V. Spatial factors of assessment of comfort of the urban environment of a large city / V. Sidorov, P. Sitnikov // Часопис економічних реформ. - 2021. - № 2 (42). - C. 70-75. 